\title{
Leprosy in Society \\ II. The Pattern of Concept and Reaction to Leprosy in Oriental Antiquity
}

\author{
OLAF K. SKINSNES, M.D., PH.D.*
}

A prior communication sKINsNes (1964), reporting on an inquiry into the social pathology of leprosy in South China, drew from folklore and tradition concepts which lay the groundwork for the thesis that leprosy is unique in the social opprobrium that it engenders, and that this social accretion is generated by the nature of the discase itself and is not essentially attributable to Biblical mistranslation or other specific tradition or writing. The social reaction is itself a malady, rooted in misconception and having tendrils extending into antiquity. Its cure can reasonably be expected to lie in exposure to an understanding of reaction causality coupled with the increasing effectiveness of advances in treatment.

In comparing the history of the social reaction to leprosy in Eastern and Western (including Middle East) cultures, certain parallel misconceptions and reactions appear. These tend to support the premise that the reactions have their origin in some unique intrinsicality relating to leprosy and that the Hebraic reaction to 'tsara'ath' as recorded in the Bible is not so much causative of the social reaction to leprosy as it is a reflection of a response to this unique pathological complex.

It will be suggested that the presence of a somewhat characteristic pattern of social reaction may therefore be evidence of the historical presence of leprosy, alone or together with complicating similarities in other diseases, even though clinically identifying description may be wanting, obscure, or inadequate as evidence.

\section{EVIDENCE OF LEPROSY IN CHINESE ANTIQUITY}

Chinesc litcrature, both medical and otherwise, with reference to lcprosy is inadequately recognized. Western references turn most commonly to the early study by wONG (1930), subsequently incorporated in the History of Chinese Medicine by wONG and wu (1936). MAXWELL (1928) referred to an early paper by EDKINS (I89I) which contained material similar to that presented by wONG. More recently LAI (cāa I 954) issued in mimeograph form (in Chinese) a summary of references to leprosy culled from readings in old Chinese medical literature over a period of twenty-five years. To this the writer, having caused a translation to be made, ${ }^{1}$ is indebted for additional information.

* Department of Pathology, University of Chicago, Chicago, Illinois, U.S.A.

${ }^{1}$ Appreciation is expressed for expert and conscientious assistance in preparing translation and transcription on the part of Mrs. Paul Yap, neè Rosalie Leung, of Hong Kong. 
WONG (I930) lists fiftecn Chinese synonyms for leprosy culled from the Chinese medical literature, the individual works cited being traditionally dated from as carly as I, Ooo B.c. to the last noted from i 744 A.D. He concludes that though the term 'lai' in modern usage designates a group of skin diseases such as psoriasis, eczema, impetigo, scabies, etc., in times past it was used synonymously with 'li', 'lieh', and 'wu chi' as a designation for leprosy. Following on this conclusion he indicates that most Chinese commentators hold that Pai Niu, a disciple of Confucius, did have leprosy ('lai') and that this represents the first recorded instance of this disease in Chinese history. 'The reference to Pai Niu's illness is found in the 'Analects' (6th century B.c.) and the pertinent statement reads: 'Pai Niu is sick. The Master went to sec him, and holding his hand through the window, cxclaimed, "Fate kills him. For such a man to have such a discase! For such a man to have such a disease!",

An earlier reference to the disease (EDKINs, I89I; WONG, I 930) is found in records of the Chou Dynasty ( I I 22-256 B.C.) known as 'The Warring States'. In the chapter called 'Calendar of the Seasons' (Yue Ling) appearing in the $L i K i$ section of this work, it is said that 'if in the middle month, of winter the proceedings of government proper to spring were observed locusts would appear and work harm, springs would all become dry, and many of the people would suffer from the itch and from leprosy.' The import of this statement in its context is that improper government will result in disasters, and leprosy is already recognized as a disaster and is here implicd to result as a punishment for moral cvil. Astrological observations in this work coincide with known star positions in early Chou times. The book as a whole, however, seems to belong to an age some centuries later, perhaps about 800-700 B.c.

Even if it is allowed that these ancient records referred to the term now used for leprosy 'lai' or 'wu chi', inquiry must be made as to the characteristics of the ancient disease and its relationship to leprosy as now known.

The Nei Ching ('Cannon of Internal Medicine') is the oldest Chinese medical classic. The traditional attribution of its authorship to Huang Ti, 2698-2598 B.C., is historically unsupportable. WONG MAN (I950) gives reasons for attributing the work to the period 479-300 B.C. and suggests that it was then subjected to several major revisions, notably in the 2nd century B.C., again shortly after I 50 A.D., yet once in the edition of 762 A.D. (still surviving), and finally the imperial edition of the Sung Dynasty, prepared in A.D. I069-I078. Despite the later alterations it is evident that the work reflects the earliest concepts of Chinese medicine available. As it is now found, this work is in two parts, the Su Wen ('Plain Questions' consisting of 8 I chapters) and the Ling Shu ('Spiritual Gate', or a classic of acupuncture, also consisting of 8 I chapters). Unfortunately, no translation has been made of the whole work and the translated portions (VEITH I949; WONG MAN I950) do not include those germane to the present argument. However, the following three statements from this work contain descriptive elements consistent with the findings in leprosy: 
'In a leper the air is not clear, thus causing the nose to rot and the skin to become ulcerated.'

'The symptoms of Ta Fung, now called I.ci Fung, is the falling of hair, eyebrows and beard and the swelling of joints.'

'Acupuncture is only applied on the discased parts of the flesh which have lost all sensation of feeling.' ('This instruction is given in speaking of the acupuncture therapy of 'I.ei Fung').

Subsequently, successive medical works add to and reiterate these observations. Thus the Pien Ch'iao Hsin Shu ('Pien Ch'iao's Classic') of about 255 B.C., states that leprosy may be caused by slecping on wet ground on a summer night, or by evil air entering the body after sexual congress thus causing both cyes to swell and 'the skin is numb and senseless and the flesh ulcerated.' In the preface of the Chia I Ching ('Acupuncture Classic') by Huang Fu-mi (2I5-282 A.D.) there is a paragraph stating that when Wang Chung-suan was twenty years old, Chung-ching (i.e. Chang Chung-ching, circa I90 A.D.) said to him, 'You are suffering from a disease which will causc your eye-brows to fall when you are forty, and death will follow in half a year's time.' Chung-suan did not believe the famous physician and ignored his medical advice. After twenty years his eyebrows fell, and death followed in 187 days. In addition to the loss of eyebrows, the chronicity of the disease process scems here to be recognized.

In the famous classic, Shang Han Iun ('Essay on Typhoid' originally titled 'Essay on Typhoid and Miscellaneous Diseases Combined') by the same Chang Chung-ching just referred to, it is stated that a person having leprosy has very little hair and eyebrows left and that his body is full of sores which have a fishy and stinking smell.

In the Hua T'o Sen Yi Pei Fang Ta Chuen ('Complete Secret Remedies of Hua T'o') attributed to the pre-eminent surgeon Hua T'o (2nd-3rd century A.D.; born circa I90 A.D.) there is an extended series of observations on leprosy as follows:

'Tai Ma Fung: The symptoms may first appear on the skin but the poison is actually stored in the internal organs. The skin is first numb without sensation, gradually red spots appear on it, then it is swollen and ulccrated without any pus. And later the disease develops to such an extent that the eyebrows fall, the eyes may become blind, the lips deformed and the voice hoarse. The patient may also experience ringing in his ears and the soles of his feet develop rotted holes; his finger joints may become dislocated and the bridge of his nose flattened.

'General Lai: All forms of leprosy result from evil air or from having provoked the deities. At first the skin is senseless, but gradually it becomes itchy as if something is running underneath. It should be treated immediately.

'Black Lai: The patient who suffers from this disease will find his voice hoarse, his vision blurred, all four limbs numb without sensation and then white spots appear in the skin. The pupil of his eye is gradually covered with white matter and gradually all vision is lost.' 
Ko Hung (A.D. 28I-36I) was an eminent Taoist concerned with therapy of discase as well as with experimentation with the 'clixir of life'. In volume 5 of his work the Chou Hou Pei Chi Fang ('Prescriptions for Emergencies'), speaking of 'Lai Ping Fang' (leprosy) there is the statement: 'At first the skin is senscless; gradually there is itching as if insects are moving underneath, and the vision becomes blurred and purplishblack swellings are found in the skin.' In another work, Kan Ying Shen Sien Chuan ('Impressions from the Lives of the Immortals') by the same author it is recorded that a military officer named Tsui Yen was suddenly afflicted with a discase. His vision became so blurred that he could not sec anything farther than a foot away, his hair and cycbrows fell, his nose became deformed, and his body was covered with sores. Everyone said that he had an evil discase that could not be curcd. An unidentificd Taoist (it should be borne in mind that as an ardent 'Taoist himself, the writer was not adverse to promoting 'laoism) gave the patient a prescription consisting of a mixture of Gleditschia sinensis (containing Gleditsaponin; traditionally a treatment in China for lupus and scrofula) and Rhem officinale (active ingredient Chrysophanic acid, traditionally used as a laxative). After this treatment, it is reported, the patient's hair grew again and he was considered cured.

The epoch of Chinese history (280-589 A.D.) lying between the end of the period of the 'Three Kingdoms' and the beginning of the Sui Dynasty was an era of confusion and political disunity with many small contending states. Little of significance is recorded of the medical history of the period.

In the Sui (589-6ı 8 A.D.) and T'ang (6ı-9o6 A.D.) Dynasties several important medical works were produced by famous physicians. Among the most prominent of these was Ch'ao Yuan-fang who was imperial physician during the reign of Sui Yang Ti $(605-6$ I 6 A.D.). By imperial command he headed a committee of doctors which wrote an extensive treatise consisting of fifty volumes divided into sixty-seven headings and containing I,76o chapters. This was the Ch'ao Shih Chu Pin Yuan Hou Tsung Lun, popularly known as the Ch'ao Shih Pin Yüan ('Ch'ao's Pathology') and published in 6ro A.D. It says of leprosy:

'All kinds of leprosy result from evil wind. In the beginning the skin loses sensation; gradually the patient feels worms moving under his skin, then his vision becomes obscure. This disease should be treated at its very beginning'.

'The symptoms of this disease in the early beginning are not noticeable, but if not treated in time the person may find himself unable to perspire, his four limbs ache, and his whole body tingles. If he scratches, sores may be formed. Or he may be unable to move his four limbs, his eyes swollen, his urine reddish yellow and his face pallid. If the poisonous worms eat the person's liver his eyebrows will fall off, if they eat the lungs the bridge of his nose will be deformed, or little lumps of flesh will grow in the nostrils thus causing difficulty in breathing; when they eat the spleen the voice becomes hoarse; when they consume the kidneys the ears will ring with 
drumming noises; if they destroy the muscles the joints will be dislocated; when they attack the skin and flesh the patient will not fecl pain.'

Sun Szu-moh (died 682 A.1).) was another great physician of the 'I'ang Dynasty. His most famous work is the Ch'ien Chin I Fang ('I'housand Golden Remedies'), in volume 23 of which, under the title 'Loathsome Sickness of I.cprosy', there is a special chapter on leprosy. It states, in part:

"There are many different kinds of 'Tai Feng (leprosy): some find themselves in a perfectly healthy state save that they have no hair or eycbrows while some find their hair and eycbrows in good condition but their bodies deformed. Some suffer from such severe chill that heavy furs cannot warm them; but some suffer from fever so severe that nothing can cool them. Some suffer severe pain due to the sores covering their bodies. Of all of these types of leprous disease some can be cured easily but some cannot be cured at all and this depends on the patient, not the physician. I have treated over six hundred patients with leprosy. Some have been cured but some do not listen to my words - thus all treatment is uscless to them'. The author also indicated that persons who suffer with leprosy may not live more than ten years and some die within five or six years.

'The medical works of the succeeding Sung (960-I 279 A.D.) and Yüan ( $1280-1367$ A.D.) Dynastics do not apparently add anything to the concepts of leprosy noted thus far. Chu Chen-heng, who lived during the latter dynasty, wrote the Pen-Ts'ao Yen I Pu W'ei ('Additions to Amplification of "the Herbal" ') where he grouped the manifestations of leprosy into five categories which he headed the 'Five Deaths'. These were (I) skin death manifested by numbness and loss of sensation; (2) pulse death when blood may form into pus; (3) death of flesh in which tissue is without pain when cut; (4) muscle death in which the fou: limbs are without strength; and in (5) bone death the bridge of the nose is flattened. According to this work, if any of these 'deaths' are found the discase cannot be cured. Presumably cure in this context meant restoration to normal.

With the Ming Dynasty ( $1368-$ I 643 A.D.) the tempo of contact with the West began to speed up but the medical literature shows no significant Western influence and the concepts concerning leprosy did not change. Thus Liu Chun, author of the $Y_{u}$ Chi Wei I ('Valuable Principles of Disease'), in speaking of leprosy under the term 'Ta Feng' states that the patient's body is covered with sores, his hair falls out, his fingers and toes are dislocated, his nose flattened and his eyes blind. Liu believed that the cause of the disease lay in sexual excess and over-indulgence in food. The proposed treatment was for both ringworm and leprosy, so the two conditions were associated but recognized as entities.

Hsich I, imperial physician during the reign of Cheng 'Te ( I 506-I $52 \mathrm{I}$ A.D.), authored the Hsieh Shih I An ('Medical Cases of Hsieh I') which in the volume entitled 'Lei Yang Chi Yao' ('Important Facts about Malign Ulccrs') dealt extensively with the treatment of leprosy. He stated, 'People with leprosy are found mostly in Honan, Fukien and Kwangtung 
(provinces). The cause of leprosy may be sexual excess while in a drunken state, or cvil air entering the body during bathing or mountain climbing.' Hsich I belicved that if the patient's hair fell out as a first sign of the disease, the poison was in the lungs; if the face became purplish the poison was in the liver; if penctrating ulcers were found on the soles of the feet, the poison was in the kidneys; if the body was covered with sores having an appearance similar to ringworm, the poison was in the spleen; and if the eyes were first affected, the poison was in the heart.

The Tung I Pao Chien ('Eastern Medical Treasury'), compiled by imperial physicians of the Ming I)ynasty, relates thrce causes of 'Ta Feng', namcly: (I) the 'luck of the place' (Feng-shui), e.g. a grave or a house which brings bad luck; (2) direct transmission of infection from parents, husband, wife, or other members of the family; and, (3) infective fomites, such as associated with public lavatories, bedding and clothing. Chang Chieh-pin, a physician with a military background, was a leader in the Wen-pu sect of medical practice which had a considerable influence on the practitioners in the Ming and Ching Dynasties. In his book, $\mathrm{PaChen}$ ('Battle Array') he indicates that he did not think that leprosy could be cured by special medical prescription, but suggested that if such a sufferer could abstain from all meat and rich food, control sexual desire, and forget all earthly things while at the same time seeking treatment early in the course of the discase, he might have a chance for a cure and a long life.

The Ch'ing Dynasty (I644-I9I 2 A.D.) produced a tremendous volume of literature including extensive compendiums with medical sub-sections such as the K'u Chin T'u Shu Chi Ch'eng ('Library Collections, Ancient and Modern'). 'This work, printed in 1726 A.D., consisted of five thousand volumes and contained three or four times as much material as the Encyclopedia Britannica. This period was a time of decline in indigenous medical practices. Thus, while there were medical schools throughout the empire in T'and Sung times, there now existed only the Imperial College of Physicians in Peking which concerned itself with the training of physicians for the imperial family. There being no supervision or licensure of the profession, virtually any one who would spend a short time perusing some medical work, or who inherited a few medical prescriptions, could set up practice. The better trained practitioners obtained their knowledge by serving as apprentices to established physicians and there was a strong tendency to keep medical observations and successful treatments as secrets within the clan. The most favoured practitioners were those with the longest family history in the art (WONG and WU, I932).

Under these conditions there was little opportunity for significant medical advance, and the concepts regarding leprosy showed little change as compared to those of earlier times. A complete review of the writings of this period is not feasible but a few references will illustrate the continuing thread of thought respecting leprosy.

In the fourth year (I 740 A.D.) of the reign of the Emperor Ch'ien Lung, imperial physicians of the stature of Wang Ping and Wu Chien, under 
imperial commission, began the compilation of the $\Upsilon_{\ddot{u}}$ Ts'uan I $^{\prime}$ Tsung Chin Chien ('Golden Mirror of Medicine') which was issued in I 749 A.D. It consists of two major sections, one on internal medicine and the second on general surgery. 'The work is predominantly a compilation of extracts, revisions, corrections and summaries of earlier medical writings. It was, however, accepted as a standard authoritative work on Chinese medicine and may therefore be regarded as representative of medical thinking at this time. The work lists three causes of leprosy: (I) climate of areas too thickly populated; (2) direct infection from persons with leprosy, or filthy conditions of public lavatories and houses, and uncleanness of bedding and clothing; and (3) neglect of personal health such as catching cold while bathing, slecping in the open air or on wet ground so that poisonous air (mal-air) could enter the body.

Ku Shih-cheng's family had been in the practice of medicine for three generations when he completed the Yang I Ta Tsuan ('Complete 'Treatise on Ulcerative Disease') during the reign of Ch'ien Lung ( I 736-I 795 A.D.). In this work he declares that leprosy does not manifest itself in some people till middle agc, but that it does occur in adolescence and in some appears as early as in infancy. It is opined that when the disease becomes manifest during middle age its cause is probably due to over-indulgence in sexual congress thus leaving the body weak and without any resistance to disease. When leprosy appears in adolescence, $\mathrm{Ku}$ Shih-cheng wrote, it does so because the body is not fully developed and negligence on the part of the parents with respect to the child's health makes the body further susceptible to disease. Once leprosy develops in such an adolescent it progresses so rapidly that only four or five of a hundred so afflicted will survive. When the disease occurs in a child four or five years of age, it is further opined, the disease is even worse for then it is congenital and entirely the fault of the parents.

This review of concepts of leprosy in Chinese medical literature will be concluded without reference to later works since the purpose of this review is to examine the indigenous development of leprosy concepts without reference to more recent Western concepts. It was shortly after the time of Ch'ien Lung, in the reign of T'ung-chih, that Gerhard Armauer Hansen announced his discovery of the leprosy bacillus (I 874 A.D.).

\section{LEPROSY IN JAPANESE ANTIQUITY}

The problem of leprosy in Japanese antiquity has been studied by veITH (1947). She concluded that,

'Ancient Japanese history of leprosy is curiously similar to that of Biblical times. Like the Levites of Israel the early Shinto priests stressed above all the need for ritual purity and fought mercilessly any affliction that was considered unclean and polluting. Impurity - whether or not it was brought about through the fault of the individual - was considered a tangible manifestation of sin. Ritual impurity could be incurred in many ways, as for instance by wounding, killing, desecration of corpses, bestiality, 
incest, tumors and leprosy. All these offenses and afflictions were lumped together under the term tsumi, or 'sin', and the offenders were placed under taboo. 'The early Shinto religion provided for purification rituals which in due time cleansed the sinners of their impurity. The lepers, however, whose impurity was of a concrete nature, could not return to the state of ritual purity by means of lustrations and ablutions; they remained subject to taboo for as long as their disease persisted.'

veITH's studies drew on numerous European reports, but set out to determine if the Japanese reaction to and treatment of leprosy antedated the earliest Christian influence in Japan. She concluded that the reaction was indigenous to the extent of not having been instigated or influenced by Christian or other European influences. In the rural communities of Japan, in early times, a known case of leprosy stigmatized the entire clan (so also in China) and because of the frequent familial appearance of the disease, the Japanese from earliest times believed that it was a hereditary disease. In the case of marriage, any hereditary trace of the disease would be rigorously searched out so as to prevent marriage alliance with any one whose relatives had been victims of the discase.

Japanese culture was from early times strongly influenced by developments in China. The relationship of such influence on the elaboration of Japanese concepts of leprosy has not been reported on. Though such study would be interesting, it is not vital to the argument of this paper and will not be pursued.

\section{LEPROSY IN INDIAN ANTIQUITY}

A few striking parallels with Oriental concepts thus far noted may be drawn from the study of Indian medicine by JuLIUS JOLLY ( I 95 I), supported by a few statements from JOHN LOWE (I947). References to the original Indian sources are given by these writers and will not be repeated here.

LOWE, after a critical appraisal, concluded that there is no doubt that leprosy was well known and described in ancient India, and referred to the Susruth Samhita, dating to about 600 B.c., as embodying traditional knowledge from still more ancient times and as referring to leprosy, including its treatment with chaulmoogra oil. He pointed out that this work describes most of the signs and symptoms of leprosy even in its milder forms and he suggested the possibility that, ' . . . in ancient times, as in the present times, leprosy in its milder forms may have been more common in India than in some other countries.' This conclusion was reached despite recognition of the likelihood that, also in ancient India, the terms used for leprosy included other dermatologic conditions such as leucoderma.

According to JOLLy, kustha, in general, referred to a very dangerous skin disease causing the most wretched deformation, the so-called 'black leprosy' (compare the Chinese 'black lai', above). The Smrtis (Indian law writings) states that sinners of the highest grade are punished with kustha in their future birth. The kusthin was not allowed to inherit (property) unless he had practised penance to remove the sin. Eighteen forms of 
kustha, divided into seven major and eleven minor forms, were recognized. From the delineation of these it is clear that though the characteristics of leprosy run as a connecting pattern through them, other disease states were not always recognized as being separate entities and were often confused with leprosy. Further divisions in classification rested on the localization of the discase in one of the 'seven elements' of the body. It was indicated that when the infection affects fat in particular there is lameness of hands, inability to walk, decay of limbs, and spreading of wounds from one part of the body to another, while with involvement of bone marrow there is prolapse or decay of the nose, redness of the eyes, maggot development in the wounds, and choking of the voice. If leprosy is in the sukradhätu (seminal fluid) of the father and in the menstrual blood of the mother, the discase is transferred to the offspring. Kustha was regarded as the worst of all diseases, and one who dies of it will be attacked by it again in future births. Coupled with the above statement that sinners of the highest grade are punished with kustha, there is here the implication that anyone having leprosy is such a sinner. This is supported by methods of treatment which prescribed that patients should adhere to a prescribed diet, practise pious ceremonies and penance, keep hair and nails short, avoid over-exertion, intercourse with women and indulgence in flesh and spirituous drinks.

Svitra, 'white leprosy', is frequently mentioned in association with kustha as a minor discase which occurs in subsequent births as a punishment for minor misdeeds. Kilāsa, thought to refer to leucoderma, is closely related to svitra and the confusion in differentiation is thought to be with the depigmented, anaesthetic macule of leprosy since both conditions are frequently met with in India. They were regarded in the past as so difficult to distinguish that in the census of $\mathrm{I} 89 \mathrm{I}$ special instructions were given on this point. According to some manuscripts, svitra or kilāsa can invade the blood, flesh and fat with resultant deterioration of the condition of the sufferer. Distinction is made as to whether the hair of the lesions is white or black, those where the hair continues black being regarded as more likcly to be cured. This point is of interest in view of LOWE's insistance that the description in Leviticus, chapter I 3, referring to whiteness of patches of the skin and associated hair speaks to the condition described as being leucoderma.

\section{LEPROSY IN PRE-CHRISTIAN WESTERN ANTIQUITY}

The following brief resume, for comparative purposes, is primarily concerned with the reaction to leprosy in the Mediterranean area and the Fertile Crescent prior to the time that Christianity achieved social status under Charlamaign (306-337 A.D.). Up to this time, the Bible in Christian hands had scarcely enough social influence to bias Mediterranean community thought with respect to leprosy. Indeed the New Testament was formed in the latter part of this period though the Old Testament, of course, had been available in Greek and Hebrew. The Hebrews were then 
a custodial rather than a missionary people, concerned with developing and maintaining their own entity against great odds and numerous conquests and exiles. 'lhough, no doubt, their thinking entered into the interplay of the total thought of the area, perhaps especially during their period of Hellenization, it goes contrary to the reading of history to assume that their thinking so influenced the area that they can be charged with having set the tone for the reaction to disease as a whole or leprosy in particular. Iater, by the time of the Mohammedan conquests, their influence (Dimon'T i 962) in Arabian medicine was substantial and Arabian medicine subsequently had great influence on the development of European medicinc. However, long before this, the pattern of social reaction to leprosy in the area was set.

'The problems of word context relating to leprosy are just as great for the Fertile Crescent languages of antiquity as is the problem of the definitive meaning of the Hebrew 'tsara'ath.' Several words that are possible candidates for association with leprosy (oppenheim i963) are herc listed:

asakku (Assyrian) - an unidentified disease having to do with uncleanness though not, according to present knowledge, necessarily referring to leprosy.

$\operatorname{gar}(a) b \bar{a} n u$ (Akkadian) - a severe skin disease given to the carc of a special physician. Sometimes used to connote 'One who is guilty.' Used also in the following sense: ' . . . if a woman (who has garbānu) has given birth to a sehhānu (malformed) child, either malc or female, a sinful man has had intercourse in the street with this woman.'

garābu (Akkadian) - a disease characterized by a white spot or pustule as a first sign.

epqu (Akkadian) - an odious skin disease. Children may be born with it. epqennu (Akkadian) - literally means 'epqu-like.'

sennitu, also sernitu (Akkadian) - a skin disease. Entymologically related

to Hebrew 'tsara'ath.' One feature of the disease was an eruption on, or discharge from, the nose.

šihhat-šeri (Akkadian) - often refers to 'consumption' but the word means 'sloughing of flesh.'

šaharšubbǔ (Sumerian loan word in Akkadian) - literally means 'covered with dust' or 'scaly.' Sufferers with this disease were expelled from the city and the word has odious connotations as used in curses.

isrubaa = šaharšubbû.

saharsuppaa = šaḩaršubbû.

li'bu (Codex Hammurapi) - divorce was permitted a man if his wife had this disease, the character of which has not been established. Either men or women, however, might have the affliction.

These terms have, for the most part, been translated as representing leprosy though there is as yet inadequate clinical characterization associa- 
ted with their use to make such translation secure. The uncertainty results either from the fact that in many instances insufficient material is available to delineate the disease meant, or perhaps as a consequence of available material not having been adequately correlated by persons knowledgeable in disease patterns and able to spot significant correlations while at the same time having the requisite linguistic skills.

For comparative purposes, in full recognition of possible fallacy in translation, some sources cmploying these words will, however, be noted.

OPPENHEIM (I956) translated fragment Sm 2073+ of the Kouyundjik collection in the British Muscum, in part, as follows:

'If he eats dust: he will become decrepit, . . . he will suffer want, alienation (?) of his god is in store for him, perplexity.

If he cats dust from a corner (of the wall) . . . he will suffer want, his mind will be at peace.

If he eats the scales of a leper (saharsuppaa): ... (he will suffer want). If he eats sand:........

This fragment dates to a 7 th century B.c. copy of a text from the 2nd millenium B.C. It is clear that the context in which the disease is referred to is unpleasant. It is coincidentally interesting to recall that it was noted (SKinsnes I 964) that in South China persons with leprosy have in recent times been accused of attempting to harm other individuals by causing them to unwittingly eat scales from leprous skin.

A monument found in I930, now in the museum at Damascus, has an inscription of a treaty between KTK (identity not established) and Arpad of Syria, concluded in about 75 O B.C. The translation by FRANZ ROSENTHAL, as presented in the text compilation by PRICHARD (I955) reads:

'If Matti'el breaks this treaty and ...., his kingdom shall be a kingdom of sand, a kingdom of sand, as long as he rules ... Everything evil on earth and in heaven and every trouble and difficulty for Arpad . . .

'(AS) this calf is slaughtered (castrated?), thus Matti'el shall be slaughtered (castrated?), and his high officials shall be slaughtered (castrated?) ... and the wives of Matti'el and the wives of his offspring and the wives of ... shall be leprous (saharsuppaa) ... and Matti'el shall be ...' It is interesting that the Tibetans have used a similar binding curse in their treaties. The Liao History (EDkins I 89 I, MAXWELL I 928) states that the Tibetans are revengeful, but cease attacking each other during times of mourning. When enemies were reconciled, the blood of chickens, pigs and dogs was mixed with wine and stored in a skull. While drinking the mixture, the oath was administered with these words: 'If you take revenge again, your crops will fail, your sons and daughters suffer from leprosy, your cattle will die, and serpents enter your tent.'

Further similar passages from other Fertile Crescent records, as for example the Persian, likewise bear witness to the presence of a disease carrying severe social opprobrium though the discase was not clinically defined in those early times. It was not till Roman times that leprosy was clinically defined in available records. By the same time it is clearly 
associated with social opprobium equivalent to that accorded the previous undefined clinical entity.

Aulus Cornelius Celsus (circa 30 A.D.) recognized and wrote briefly concerning leprosy under the heading, 'Of Elephantiasis'. 'Translated from the Latin (LEE I 83I) he described the affliction as follows:

'That disease which the Greeks call elephantiasis is very common in some countries, although scarcely known in Italy, and is of the chronic class. The whole body is affected in such a manner that even the bones may be said to be diseased. The surface of the body frequently exhibits blotches and tumours; their colour is gradually converted into a black; the surface of the skin is unequally thick and thin, hard and soft, assuming a squamous appearance; the body becomes emaciated, the mouth, the calves, and feet swell; when the discase is become inveterate, the fingers and toes are involved in the swelling, slight fever arises, which soon carries off its victim overwhelmed with so many afflictions.'

Judging from his description of the disease, Celsus apparently kept his clinical detachment from the emotional aspects of the problem of leprosy in contrast to his successor Aretaeus who reflected the attitude and concepts of the Greeks in the second century A.D. They referred to leprosy under the terms: elephantiasis, elephas, leontiasis, and satyriasis. Aretaeus wrote (ADAMS I 856):

'The disease is also called Leo, on account of the resemblance of the eyebrows, as I shall afterwards explain; and Satyriasis, from the redness of the cheeks, and the irresistible and shameless impulse ad coitum. Moreover it is also called the Heracleian affection, insomuch as there is none greater and stronger than it.

'Wherefore the affection is mighty in power, for it is the most powerful of all in taking life; and also it is filthy and dreadful to behold, in all respects like the wild animals, the elephants. And from the disease there is no escape, for it originates in a deadly cause . . . . .

'But the commencement of the disease gives. no great indication of it; neither does it appear as if any unusual ailment had come upon the man, nor does it display itself upon the surface of the body, so that it might be immediately seen, and remedies applied at the commencement; but lurking among the bowels, like a concealed fire it smoulders there, and having prevailed over the internal parts, it afterwards blazes forth on the surface, for the most part beginning like a bad signal fire on the face, as it were its watch-tower; but in certain cases from the joint of the elbow, the knee, the knuckles of the hands and feet . . . Tumours prominent (referring to nodules in the skin), not continuous with one another anywhere, but thick and rough, and the intermediate space cracked, like the skin of the elephant. Veins enlarged, not from abundance of blood but from thickness of the skin; and for no long time is the situation of them manifest, the whole surface being elevated equally in the swelling. The hairs on the whole body die prematurely, on the hands, the thighs, the legs, and again on the pubes; scanty on the chin, and also the hairs on the 
head are scarce. And still more frequently premature hoariness and sudden baldness; in a very short time the pubes and chin naked of hair, or if a few hairs should remain, they are more unseemly than where they are gone. The skin of the head deeply cracked; wrinkles frequent, deep, rough, tumours on the face hard, sharp; sometimes white at the top, but more green at the base ... tongue roughened with vari, resembling hailstones; not unusual for the whole frame to be full of such (and thus also in unsound victims, the flesh is full of these tubercles resembling hail) ... eyes misty, resembling bronze; eye-brows prominent, thick, bald, inclining downwards, tumid from contraction of the intermediate space; colour livid or black; eyc-lid, therefore, much retracted to cover the eyes, as in enraged lions; on this account it is named leontium. Wherefore it is not like to the lions and elephants only, but also in the eye-lids 'resembles swift night.' Nose with black protuberances, rugged; prominence of the lips thickened, but lower part livid; . . . ears red, black, contracted, resembling the elephant, so that they appear to have a greater size than usual; ulcers upon the base of the ears, discharge of ichor, with pruritis; shrivelled all over the body with rough wrinkles; but likewise deep fissures, like black furrows on the skin; and for this reason the disease has got the name of elephas. Cracks on the feet and heels, as far as the middle of the toes; but if the ailment still further increases, the tumours become ulcerated, so that on the cheeks, chin, fingers, and knees, there are fetid and incurable ulcers, some of which are springing up on one part, while others are subsiding on another. Sometimes, too, certain of the members of the patient will die, so as to drop off, such as the nose, the fingers, the feet, the privy parts, and the whole hands; for the ailment does not prove fatal, so as to relieve the patient from a foul life and dreadful suffering, until he has been divided limb from limb. For it is long-lived, like the animal, the elephant.....

'When in such a state, who would not flee; - who would not turn from them, even if a father, a son, or a brother? There is danger, also, from the communication of the ailment. Many, therefore, have exposed their most beloved relatives in the wilderness, and on the mountains, some with the intention of administering to their hunger, but others not so, as wishing them to die.'

This quotation from Aretaeus has been presented at length because it is frequently referred to only briefly but as being generally accepted as representing one of the earliest Western clinical delineations of leprosy and because it throws light also on the social reaction to the disease at this early period. Neither its tone nor its background suggests any influence from the Bible in its conception. It would seem clear that leprosy, the same disease as now recognized, had already called forth social opprobrium similar to that to which it has been subjected even unto more recent times.

In the light of the presentation by Aretaeus it is difficult to see why some (MOISER I 96I) who wish to change the name 'leprosy' should choose as a substitute 'ElEPHANTIAS GRAECORUM' if the motive is to avoid the 
traditional social context of this disease and separate it from the moiety of misconceptions to which its sufferers have been subjected down through the ages.

\section{SUMMARIZING DISCUSSION}

Taken in composite, the Chinese concepts of leprosy, outlined in their historical development above, can be summarized as follows and show a strong similitude to the manifestations of leprosy as it is recognized today: I. Extensive nodular lesions involving the skin, most prominently of face and extremities.

2. Extensive ulceration of lesions and prominent ulcerations on the soles of the feet.

3. Paralysis of extremities and anacsthesia of lesions and extremities.

4. Loss of cyebrows and hair.

5. Lesions of the nose with flattening of the nose.

6. Disease involvement of eyes with eventual blindness possible.

7. Sometimes hoarseness of voice.

8. Chronicity in terms of years (5-10).

9. Depigmentation of some lesions; erythema and hyperpigmentation of others.

Io. Association with unhygienic and crowded living conditions.

I I. Increased susceptibility to the disease in association with debilitation.

I2. Transmission by contact with persons having leprosy.

I3. Loss of sweating ability, though not specifically noted that this loss is lesion localized.

I4. Susceptibility of all age groups to leprosy.

It is true, of course, that the recognition of these characteristics was diluted and interpreted in the context of associated misconceptions so that they did not have the same force of understanding that they now represent. Nevertheless, they indicate that Chinese society, from ancient times recognized as an entity the disease known in modern times as leprosy even though, as was inevitable before the dawn of bacteriological understanding, they included other conditions with leprosy to make a dermatological moiety in which the component parts were not always discernible as separate entities. Recognizable characteristics of leprosy are, however, described as early as about 500-300 B.c.

Noteworthy and interesting is the fact that what seem to be the earliest clear clinical delineations of leprosy in Greek and Chinese medicine were the descriptions by Aretaeus and Hua T'o respectively and that these physicians were approximate contemporaries.

The social reaction of the Chinese ancients was of a pattern compatible with that of the folklore of their heirs. The reaction pattern may be summarized as :

I. Leprosy was regarded with horror and its occurence was considered a major calamity. 
2. The cause of leprosy was associated with sexual and other excesses, or by the entrance into the body of malign influences, such as 'mal-air'.

3. The appearance of leprosy in an individual was associated with concepts of retribution for moral delinquency provoking the deities.

4. L .eprosy was considered incurable save, perhaps, by magical means or penance.

5. The clothing, bedding and discharges from persons with leprosy were considered contaminated and possible sources of infection.

6. The disease was regarded as congenital and hereditary by some and was then regarded as being due to fault on the part of the parents.

These concepts are reinforced by repeated statements that leprosy is an evil disease, that people suffering from it are morally delinquent and by references to persons with leprosy being sent to isolation in caves or other special places. The concepts are essentially the same as those previously reported (skinsNes 1964) as current in the present-day folklore of South China.

The supplementary brief reviews of the historical patterns of concept and reaction to leprosy in Japan and India reveals that these, though not identical, are of a pattern with that of China. Likewise, evidence is noted, notably from Aretaeus, indicating that the reaction pattern of the Mediterranean area was similar. Evidence from the antique lands of the Fertile Crescent is fragmentary but, while not giving clinical evidence for the presence of leprosy, does record a reaction pattern to an undelineated disease or disease moiety similar to that noted historically in the other areas considered. This, in view of the uniqueness of the social reaction to leprosy in broad areas where leprosy is defined, suggests that the presence of similar patterns of social opprobrium to a disease may constitute evidence that leprosy was the basic object of this reaction though the disease may not be clinically defined in available records.

Surely it is evident that by the time of Aretaeus (circa I50 A.D.), leprosy was recognized as a clinical entity very similar to its present day pattern. Also, it is clear that by this time the pattern of social reaction to it was set in at least the eastern portion of the Greco-Roman area. It is most unlikely that the Greek Septaguint translation of the Hebrew Old T'estament was responsible for this reaction. It also seems highly improbable that leprosy was non-existent prior to the time of Aretaeus and suddenly appeared as a clinical and social entity in the interval between the Septaguint translation (circa 200 B.c.) and the writings by Aretaeus.

A far more probable course in history, one may suggest, was the gradual isolation by astute ancients of the major irritant in the disease moiety that had from olden times been calling forth such social fear and displeasure. Other elements having been discarded, at least in part, with the growing clinical acumen, the accretion of social opprobrium fell to leprosy which was for centuries to remain a puzzling and frightening pathologic complex. Quite probably the seventy-two (MARGOLIs and MARX 1958) wise scholars who produced the Septaguint translation were 'modern' enough 
to be aware of the developing medical thinking and discase delincation. Surcly they were aware of the implications of the word 'tsara'ath' and, being advanced scholars, they were probably justified in choosing the word 'lepra' which was then very likely on the way to taking on the connotations noted by Aretacus. It would secm most uncharitable and unresponsible two thousand and more years removed from the scene to accuse these advanced scholars of not being able to choose a word from their social milicu that would most closely carry the implications of so important a concept as 'tsara'ath'.

'The Bible, not being a book of 'revealed' medical facts, rather than creating the social reaction to leprosy, reflected this social reaction in order to make certain theological concepts clear in terms understandable by the society in which it was put together. In the ensuing centuries these concepts of leprosy as stratified in this Scripture, as wcll as in other works in many lands, continued to influence society's reactions. In-so-far as the Bible carried these concepts to areas that would otherwise have no experience with or concept of leprosy, it helped to keep alive concepts of a disease for which no alternative explanation would be available till the dawn of bacteriological and pathological understanding of disease causation and pathogenesis.

If today the ancient misconceptions of leprosy as reflected in the Bible continue to plague society, the blame can hardly be laid on the shoulders of the seventy-two but must be faced up to by this same world society which today prides itself on its science-revealed understanding.

\section{S U M M A R Y}

A survey of Chinese medical writings indicates that leprosy was recognized in China as early as 500-300 B.c. and clinically fairly well delineated by the 2-3rd centuries A.D. Extant records further show that the social reaction to this disease was already set in this early period and that it was essentially of a pattern with that previously reported for present-day South China. The continued re-iteration and elaboration of these early concepts and reactions to leprosy through the intervening centuries, in a society far removed from influencing contact with the Bible, strongly suggests that the Bible is not essentially responsible for the creation of the social opprobrium associated with leprosy in many portions of the world. It is rather concluded that there is some unique intrinsicality relating to leprosy that makes it subject to society's opprobrium.

Comparative reference to the historical reaction to leprosy in Japan and India reinforce these conclusions. Likewise contributory are some Middle East and Greco-Roman contributions which seems to be free of Biblical influence.

Accordingly, it is suggested that the presence of a pattern of social reaction, similar to that here noted, to a clinically undelineated or undefined disease may serve as evidence that the disease in question may well be leprosy. 
'The problem of the reason for this remarkable reaction to leprosy in so many disparate socictics, though not necessarily all, remains to be considered and will be the subject of a following communication.

\section{References}

Annms, F. (translator), The Extant Works of Aretaeus, the Cappadocian. (1856), Iondon: 'The New Sydenham Society, pp. 368-372.

imont, м. I., Jews, God and History. (1962), New York: Simon and Schuster.

Eıkins, J., C'hina Medical Missionary Journal, March I89ı.

Jol.t.y, J., Indian Medicine. (IgOI), Irans. from German and supplemented with notes by Kashikar, C. G., printed privately by the translator. Poona, India: M. I). Gurjar, printed, I95 I. I.AI, s. н., The Disease Ieprosy in Chinese History. Circa 1954 (in ('hinese). A twenty year study privately mimeographed and circulated.

I.EE, A. (translator), 'Of Elephantiasis' by Aulus Cornelius Celsus in Celsus de Medicine, (1831), I.ondon: E. Cox, pp. 23 I-232.

I.OWE, J., 'Comments on the History of Leprosy', (1947), I.ep. Review, r8: 54-64.

makgoilis, м. \& marx, A., History of the Jewish People (1958); New York: Meridian Books, Inc., p. I3O.

maxweli, J. L., 'I eprosy, the Problem of its Eradication from China', (1928), China Medical Journal, $42: 867-879$.

moiser, B., “'Leprosy”: Ancient and Modern,' (I96 I), The Star, 20: 5-6.

oppenneim, A. L., The Interpretation of Dreams in the Ancient Near East, with a Translation of an Assyrian Dream-Book. (1956), Philadelphia: Am. Philosophical Soc., p. 273.

oppenheim, A. I.., ( 1963 ), Personal communication.

Pritchard, J. B., Ancient Near Eastern Texts Relating to the Old Testament. (I955), Princeton: Princeton Univ. Press, 2nd ed., pp. 503-504.

skinsnes, O. K., 'Leprosy in Society (based on South China),' (I964), Lep. Review, 35, I, pp. $2 \mathrm{I}-35$.

verth, I., 'A Japanese Picture of Leprosy.' (r 947), Bull. Hist. Med., 2r : 905-9 7.

wonc, к. с., 'The Early History of Leprosy in China.' (r930), China Med. Jour., 44: $737 \mathrm{ff}$. wong, K. C., \& wU, L. T., History of Chinese Medicine ( 1963 ), Shanghai: National Quarantine Service, pp. 209-2II, etc. 